DOI: 10.20472/IAC.2019.045.012

\author{
HANNAH DUNGA \\ VAAL UNIVERSITY OF TECHNOLOGY, South Africa
}

\title{
THE IMPACT OF TECHNOLOGICAL REVOLUTION ON POVERTY: A CASE OF SOUTH AFRICA
}

\begin{abstract}
:
The world has experienced a massive transformation since the establishment of the first industrial revolution which seemed as a breakthrough for humankind. The first industrial revolution transformed from an agrarian and handcraft world to the use of machines that were powered by water and steam. This was followed by what is called the second and subsequently the third industrial revolution the two led to an establishment of electric power to create mass production and the use of electronics and information technology to automate production. In a short while technology evolved rapidly birthing what is so called the current fourth industrial revolution. Unlike the past three evolutions, the fourth industrial revolution has rapidly transformed the way of life to a sophisticated digitalized world where everything is made instant. In as far as such improvements in the technological sphere are important, the fourth industrial revolution is receiving so much critic in most industries, this paper highlights the effects of the fourth industrial revolution on the poor people or those on the boundary of poverty. The premise of the paper is that Industry 4.0 as it is also known, has made life better and easier for those that are involved and has paradoxically made the gap between the educated and the uneducated even wider. The usage of technological advancements is associated with income in a way that those that do not have access to such income as would enable them to afford any technological gadget and hence know how, are left behind by unprecedented gaps. This paper therefore analyses the relationship between technological advances proxied by access to cell phone and data, and poverty in South Africa. To achieve this the paper will employ data obtained from 2017 General household survey data from STATS SA. The apriori expectation is that households that are able to move with technology do so at very high opportunity cost and hence may trade off technology with basic needs that end up pushing them deeper into poverty.
\end{abstract}

\section{Keywords:}

Fourth industrial revolution; poverty; technology; households; trade-off

JEL Classification: 130 


\section{Introduction}

The beginning of the industrial revolution can be traced back to the $17^{\text {th }}$ century, with Britain being the main player in the establishment of this great advent in history. The industrial revolution can be described as an economic upheaval which led to a dramatic change of people's livelihood from the agrarian rural livelihood to a city and town livelihood (Blinov, 2014). Before the first industrial revolution most people resided in small, rural communities where their daily existence revolved around traditional farming. There were not much economic activities then and most people were very poor and were sustained by what they could salvage from their small farms. Life for an average person was difficult, as incomes were meagre (Allen, 2006). Manufacturing was often done in people's homes by using hand tools or basic machines, as such, not much could be produced, as most of the production was mainly for own consumption (Broadberry and Fremdling, 2008). The introduction of industrialization marked a shift from the agrarian livelihood to a powered, special-purpose machinery, factories and mass production of products. Industrialization has been improving gradually since its establishment. The first part of this economic shakeup is described as the first industrial revolution led by Britain and took place around $17^{\text {th }}$ century, followed by other countries like United States of America and many more (Crafts 1977). Developments of the first industrial revolution led to the shifting of farming as way of living to an industrialized development (Crafts, 1996). Relating to the industrialization that took place in the USA during this time, (Blinder, 2006) stipulates that the beginning of this upheaval is attributed to Samuel Slater who opened the first industrial mill in the United States in 1790 with a design that borrowed heavily from a British model. Slater's pirated technology greatly increased the speed with which cotton thread could be spun into yarn. While he introduced a vital new technology to the United States, the economic take-off of the Industrial Revolution required several other elements before it could transform American way of life.

Soon after the first industrial developments which led to the growth of industries, such as coal, iron, railroads and textiles, the second industrial revolution witnessed the expansion of electricity, petroleum and steel. The third revolution subsequently emerged with all new types of energy whose potential surpassed its predecessors which is the nuclear energy. This revolution witnessed the rise of electronics with the transistor and microprocessor but also the rise of telecommunications and computers. This new technology led to the production of miniaturised material which would open doors, most notably to space research and biotechnology. Presently we are now at the fourth industrial revolution which is driven by the internet (Lee et al., 2018). This is the first industrial revolution rooted in a new technological phenomenon of digitalization rather than in the emergence of a new type of energy. This digitalization enables people to build a new virtual world from which they can steer the physical world. With such advancements in technology it has also led to accelerated economic growth across the globe, especially for those countries that were the first movers and leaders of the fourth revolution. While it is agreeable that the world has 
experienced enormous benefits and economic growth from the first to the present industrial revolution, the experiences are not similar in all countries this is particularly unique in developing countries where poverty and inequalities are still very high. For example, in South Africa, according to STATS SA (2018), more than half of the population in South Africa's is living in poverty. Ibid further states that according to the Poverty trends report from 2006 to 2015 , 30.4 million people (55.5\% of the population) is living in poverty which is up from the $53.2 \%$ or 27.3 million people reported in 2011 (STATSSA, 2018). The question lies in the fact that as the world is changing technologically shouldn't such developments allude to better livelihood meaning prosperity, greater equality, better education, healthier lives and reduced poverty? But it seems that the increasing in technological revolution is leading to a widening gap between the poor and the rich. Thus, this paper intends to analyse the effects of technological revolution over time and its impact on poverty at household level in South Africa. The premise is that it can be taken for granted that the revolution is beneficial for everyone. The advent of technology and access to the internet comes at a cost, and a higher cost in other countries than others. The household or individual demand for access to technology especially for those on the periphery of poverty may come at a high opportunity cost, in most cases the trade-off is with very basic needs like food, housing or clothing. The choice given to the poor is either they trade off and move with the fast-moving technological world or choose to keep the resources for other demands like food and get left far behind as everyone else is moving fast ahead.

\section{Literature review}

There is extensive literature of industrial revolutions in general (Clark, 2001; Allen, 2006; Ladenburg, 2007). There is still a gap in the literature in regard to the relationship between the fourth industrial revolution and poverty. The assumption generally would be that the advent of the fourth revolution should aid the poverty reduction efforts. The unexpected association would be the negative effect that the fourth industrial revolution may have on poor households or those on the margins of the poverty threshold. From the onset of technological revolution which has revolved from the first, second, third and lastly the fourth which is the present state, the world has experienced exponential developments in technology leading to economic growth all over the world but while the proverbial pie is getting bigger, unfortunately it's not being shared with everyone or at least not equally. Substantially there is a growing number of poverty levels especially in developing countries (Blank, 2003; Affairs, 2004; Davis and Sanchez-martinez, 2014; Grobler and Dunga, 2014; The World Bank, 2018). Although one may not directly assign the blame to the fourth revolution, there is clear indication that as other parts of the world are benefiting, others are being left behind. The fourth industrial revolution by its nature has the potential of leading to very high and advanced ways of life for those moving together with the changes, however for those left behind will be left far behind. Defining poverty, the pioneers of 
poverty have defined poverty as the lack of enough money to satisfy basic physical needs (Booth, 1889; Rowntree, 1901). World Bank (2018) report on poverty levels argues that even though extreme levels of poverty have seemingly decreased, the struggle is far from being resolved as the problem has now shifted and concentrated in one area. Ibid further describes sub-Saharan region as one area where poverty levels have increased. Between 1990 to 2015 the number of people living under extremely levels of poverty increased from 278 million to 413 million making this region a home of more extremely poor people than in the rest of the world combined. We tend to think that technology is the answer to poverty, but poverty in general has two main lines of thought, there is the first group of perspectives traditionally referred to as Conservative Theories of Poverty which attributes this condition to individual deficiencies (Ryan, 1976; Schiller, 1989; Bradshaw, 2006). The second group takes cognisance beyond the individual and attributes poverty to broader social phenomena (liberal or progressive) (Bradshaw, 2006). Regardless of how poverty is conceptualised, the effects of poverty are way unacceptable. There hasn't been much research in regard to the impact of technological revolution on poverty as most studies have attributed the technological advancement to the positive effects which does not regard those in poor countries who barely survives on merger share. As explained earlier that, the usage of technological advancements is associated with income in a way that those that do not have access to such income as would enable them to afford any technological gadget and hence somehow, are left behind by unprecedented gaps.(Deloitte, 2017) in their study with executives of companies found a lot of optimism of industry 4.0, however there were no clear understanding of the impact of the revolution on the current poverty. This paper therefore analyses the relationship between technological advances proxied by access to cell phone and data, and poverty in South Africa.

\section{Methodology and sample}

This section describes the research methods adopted in this study, the data used and the sources of the data. The section further explains the calculation of poverty in detail, as this is used in the analysis section to demonstrate the link that exist between technological advances and poverty.

\subsection{Data collection}

The study employed the 2017 General Household Survey data obtained from STATS SA. A total of 21225 households were involved in the survey, after data cleaning 415 data points were removed because they had abnormalities hence were regarded unfit for the study. In the end the study used 20810 households. 


\subsection{Calculating the poverty status of household}

The main objective of the study was to analyse the impact of Technological revolution on poverty in South Africa. This was based on the fact that to keep up with the trend of new development in technology, poor households are forced to make a trade-off between the basic necessities and technological demands. To achieve the objective the study analyses the poverty status of households using income of household as the basis to the calculate the poverty status of household which then is related to the ownership of gadgets such as cell phone, Tv and other expenses (pay of TV license and pay for mobile data).

The Poverty status of households was calculated using the 2017 South African poverty line. The first step was calculating the poverty line for each household, to achieve this the number of people in a household was obtained then was multiplied by the 2017 poverty line. Thereafter to obtain the poverty status of the household, the obtained household poverty line was subtracted from the net monthly income of the household. All the households found to be below the 2017 poverty line were regarded as poor households and all those above the poverty line were regarded non-poor household.

\subsection{Model specification}

The study employed descriptive analysis and cross tabulations. The cross tabulations helped to determine the access of technological advancements for households which further gives an indication whether if the poor are also amongst the group of people accessing any gadgets. The apriori expectation is that households that are able to move with technology do so at very high opportunity cost and hence may trade off technology with basic needs that end up pushing them deeper into poverty.

\section{Results and interpretation}

\subsection{Descriptive results}

This section presents descriptive results of the study as follows:

Table 1 presents results for household size of the study population its shows that from the total of 20810 households, the maximum number of households was 1 and the maximum was 22. 
Table 1. Household size

\begin{tabular}{l|lllll} 
& $\begin{array}{l}\text { Total } \\
\text { number } \\
\text { of } H / H\end{array}$ & Minimum & Maximum & Mean & $\begin{array}{l}\text { Std. } \\
\text { Deviation }\end{array}$ \\
$\begin{array}{l}\text { Household } \\
\text { size }\end{array}$ & 20810 & 1.00 & 22.00 & 3.4120 & 2.32533 \\
\hline
\end{tabular}

Figure 1 of the study presents results of gender distribution of the sample it shows that 43 percent of the households were headed by females and 57 percent were male headed households.

Figure 1. Gender of household

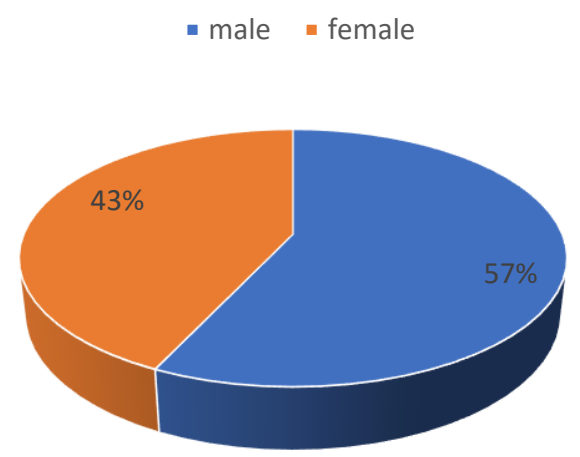

Table 2 of the study presents results of gadget ownership of households, it shows that ownership of electronics which are part of the new era technology is well populated in the sample. 82 percent of the households indicated that they owned TV, 96 percent owned cell phones. On the other side of the equation is the expenses that accompany these gadgets which in this case is the use of mobile data and paying for TV subscription. The table indicates that 40 percent and 53 percent respectively of the population do pay something in order to make use of these gadgets. The study further analysed which households exactly do pay for these expenditures the results are presented later in the paper.

\section{Table 2. Ownership of gadgets}

\begin{tabular}{l|ll} 
& Yes & No \\
\hline Own TV & $82 \%$ & $40 \%$ \\
Pay DSTV & $40 \%$ & $60 \%$ \\
Use mobile data & $53 \%$ & $40 \%$ \\
Own cell phone & $96 \%$ & $40 \%$
\end{tabular}


Table 3 presents results of monthly income of households in the study in categories, its shows that most of the households were in the bracket of 2001 to 5000 rand as monthly income. Very few households were in the bracket of 30001 and above the study further analysed the poverty status of households the results are shown in figure 2 .

Table 3. Monthly income of household in categories

\begin{tabular}{l|ll}
$\begin{array}{l}\text { Household Income } \\
\text { Categories }\end{array}$ & in Frequency & Percentage \\
\hline $\begin{array}{l}\text { 0-500 } \\
510 \text { to } 1000\end{array}$ & 870 & 4.2 \\
1001 to 2000 & 1543 & 7.4 \\
2001 to 5000 & 2633 & 12.7 \\
5001 to 10000 & 6179 & 29.7 \\
10000 to 30000 & 4845 & 23.3 \\
30001 above & 3568 & 17.1 \\
Total & 1172 & 5.6 \\
& 20810 & 100.0
\end{tabular}

Figure 2 presents results of household poverty status. It shows that 36 percent of the households were poor and 64 percent were not poor the results are according to the study's measurement of household poverty status as discussed in methodology section.

\section{Figure 2. Poverty status of household}

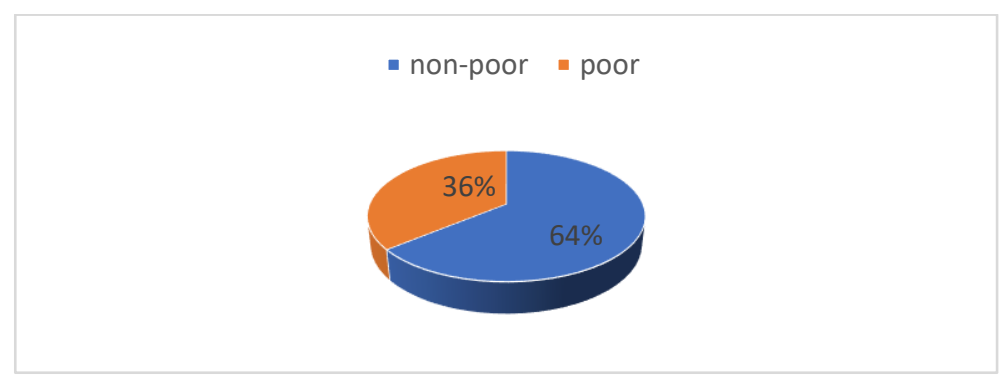

\subsection{Results on cross Tabulation Analysis}

This section presents cross tabulation results between the poverty status of households and the use technological advanced gadgets as follows; 
Table 4. cross tabulation between poverty status and cell phone ownership

\begin{tabular}{|c|c|c|c|c|c|}
\hline \multicolumn{2}{|c|}{ Poverty status } & \multirow{2}{*}{ count } & Owns cell & No Cell & Total \\
\hline & & & 12783 & 510 & 13393 \\
\hline $\begin{array}{l}\text { non- } \\
\text { poor }\end{array}$ & $\begin{array}{l}\text { \%within poverty } \\
\text { status }\end{array}$ & & $96.00 \%$ & $4.00 \%$ & $100.00 \%$ \\
\hline Poor & & count & 7067 & 350 & 7417 \\
\hline & $\begin{array}{l}\% \text { within poverty } \\
\text { status }\end{array}$ & & $95 \%$ & $5 \%$ & $100.00 \%$ \\
\hline
\end{tabular}

Table 4 presents cross tabulation results between poverty status and cell phone ownership of the households, it shows that 96 percent of the non-poor households owned cell phones and only 4 percent of the non-poor households did not own cell phones. For those that were found to be in the category of poor households, 95 percent indicated that they owned cell phones while 5 percent indicated they did not own cell phones. This is an indication that regardless on someone being poor they still buy cell phones which in this study are regarded as part of the new area developments. The question rests on the fact that how does this impact their day to day livelihood.

Table 5. cross tabulation of poverty status and use of mobile data

\begin{tabular}{|c|c|c|c|c|c|}
\hline \multicolumn{2}{|c|}{ Poverty status } & count & Use mobile & Not use & Total \\
\hline $\begin{array}{l}\text { non- } \\
\text { poor }\end{array}$ & $\begin{array}{l}\text { \%within poverty } \\
\text { status }\end{array}$ & & $57 \%$ & $43 \%$ & 100 \\
\hline poor & & count & 3386 & 4031 & 7417 \\
\hline & $\begin{array}{l}\% \text { within poverty } \\
\text { status }\end{array}$ & & $46 \%$ & $54 \%$ & $100 \%$ \\
\hline
\end{tabular}

Further to the results in table 4 , table 5 presents results of cross tabulation analysis between the poverty status of households and the purchase of mobile data. It shows that 46 percent of the poor household do buy data for mobile usage and 54 percent do not buy data. Despite the fact that they are more who do not buy data, but the variation is not much 
indicating that the ownership of mobile phones comes with cost effects. Poor households being part of the population whose expenditures is on mobile data becomes of interest.

Table 6. cross tabulation between poverty status and TV Ownership

\begin{tabular}{|c|c|c|c|c|c|}
\hline \multicolumn{2}{|c|}{ Poverty status } & & Owns TV & Not own TV & Total \\
\hline $\begin{array}{l}\text { non- } \\
\text { poor }\end{array}$ & $\begin{array}{l}\text { \%within poverty } \\
\text { status }\end{array}$ & & $82 \%$ & $18 \%$ & $100 \%$ \\
\hline \multirow[t]{2}{*}{ poor } & & count & 6036 & 1381 & 7417 \\
\hline & $\begin{array}{l}\% \text { within poverty } \\
\text { status }\end{array}$ & & $81 \%$ & $19 \%$ & $100 \%$ \\
\hline
\end{tabular}

Table 6 presents cross tabulation results of TV ownership it shows that 81 percent of the poor households owned a TV during the time the study was conducted, and 19 percent of the household did not own a TV. The study further analysed the cost of owning a TV which part of it is to pay for TV subscription, table 7 shows the results of TV subscription payment between poor and non-poor households it shows that 38 percent of the poor household indicated that they do pay for TV subscription the question still rest on the fact that how is it that poor households who fall below the poverty line are able to spend on such luxuries.

Table cross tabulation between poverty status and DSTV payment

\begin{tabular}{|l|l|l|l|l|}
\hline Poverty status & & Pay DSTV & $\begin{array}{l}\text { Don't pay } \\
\text { DSTV }\end{array}$ & Total \\
\hline $\begin{array}{l}\text { non- } \\
\text { poor }\end{array}$ & $\begin{array}{l}\text { \%within pount } \\
\text { status }\end{array}$ & 5546 & 7847 & 13393 \\
\hline poor & & $41 \%$ & $59 \%$ & \\
\hline $\begin{array}{l}\text { \% within poverty } \\
\text { status }\end{array}$ & count & 2846 & 4571 & 7417 \\
\hline
\end{tabular}

\section{Conclusion}

The study's main objective was to analyse the impact of technological revolution on poverty in South Africa. To achieve this the study employed descriptive statistics and cross 
tabulation analysis to determine if there exist poor households in the sample and further analysed if these households are in the group of the population which makes use of the new technologically advanced gadgets such as Cell phones and TV. The results indicated that 36 percent of the households were poor meaning that these households had a total income that was below the household poverty line. The study further analysed the usage of technologically advanced gadgets such as cell phones and TV if poor households do make use of such gadgets but also the cost in terms of buying data and paying for TV subscription. Having proven based on the results that some poor households were amongst the group of those making use of these gadgets which comes at a high cost. The only explanation as to how these poor households manage to attain such expensive items on their little income is that households that are able to move with technology do so at very high opportunity cost and hence may trade off technology with basic needs that end up pushing them deeper into poverty. This paper serves as a preliminary research in this area of technological advancement and poverty. There is need to go deeper and address the actual expenditure patterns of the household in regard to how much is spend on food and non-food items which in the end will give good results on the effects of technological advancement and poverty. There is also a need to analyse the nexus between food security status of poor household in South Africa and the poverty status based on the industrial revolution. This will help to ascertain whether if the households found to be poor according to the measure of poverty established by this study, are the same households who are moving fast in technology though poor.

\section{References}

Booth C. 1889. Life and labour of the people in London. Williams and north gate

Affairs, M. of foreign (2004) Poverty, policies and perceptions in Tanzania.

Allen, R. . (2006) 'Explaining the British industrial revolution from the perspective of global wage and price history'.

Blank, R. M. (2003) 'Selecting Among Anti-Poverty Policies: Can an Economist be Both Critical and Caring?', Review of Social Economy, 61(4), pp. 447-469. doi: 10.1080/0034676032000160949.

Blinder, S. . (2006) 'Offshoring: The Next Industrial Revolution?', Foreign affairs, 85(2), pp. 113-128.

Blinov, S. (2014) 'causes of the British Industrial Revolution', (53642). Available at: http://mpra.ub.unimuenchem.de.

Bradshaw, T. K. (2006) Theories of Poverty and Anti-Poverty Programs in Community Development. 05. CA 95616.

Broadberry, S. and Fremdling, R. (2008) 'Unifying the European Experience: An Economic History of Modern Europe, Volume 1: 1700-1870', 1(April), pp. 1-41.

Clark, G. (2001) 'THE SECRET HISTORY OF THE INDUSTRIAL', (November 2001).

Crafts, N. F. . (1996) 'American Economic Association The First Industrial Revolution: A Guided Tour for Growth Economists Author ( $\mathrm{s}$ ): Nicholas F . R. Crafts Source : The American Economic Review, Vol 
. 86 , No . 2 , Papers and Proceedings of the Hundredth and Eighth Annual', The American Economic Review, 86(2).

Davis, E. P. and Sanchez-martinez, M. (2014) 'A review of the economic theories of poverty', (435), pp. 165.

Deloitte (no date) The Fourth Industrial Revolution is here-are you ready?, Deloitte Insights.

Grobler, W. C. J. and Dunga, S. H. (2014) 'An Analysis of the Perceptions of Causes of Poverty among Grant Receiving and Non-Grant Receiving Households', (October), pp. 1-9.

House, C. R. (no date) 'Poverty's Cause and Effect, New World Outlook 100 Year Review'.

Ladenburg, T. (2007) 'Chapter 1 The Industrial Revolution', Digital History, pp. 1-6.

Lee, M. et al. (2018) 'How to Respond to the Fourth Industrial Revolution, or the Second Information Technology Revolution? Dynamic New Combinations between Technology, Market, and Society through Open Innovation', journal of open innovation. doi: 10.3390/joitmc4030021.

Ryan, W. (1976) Blaming the victim. New York: Anchor.

Schiller, B. R. (1989) The economics of Poverty and Discrimination. Englewood Cliffs NJ: Prentice Hall.

The World Bank (2018) Poverty and Shared Prosperity 2018: Piecing together the poverty puzzle. doi: 10.1596/978-1-4648-0958-3. 